\title{
Use of Prolactin Inhibition in the Treatment of Peripartum Cardiomyopathy
}

\section{O uso de inibidores de prolactina no tratamento de cardiomiopatia periparto}

\author{
James D. Fett ${ }^{1}$ \\ ${ }^{1}$ Department of Adult Medicine, Hospital Albert Schweitzer, \\ Deschapelles, Haiti \\ Rev Bras Ginecol Obstet 2016;38:477-478.
}

\begin{abstract}
Address for correspondence James D. Fett, MD, Department of Adult Medicine, Hospital Albert Schweitzer, Deschapelles, Haiti, c/o 2331 Mt. Hood Ct. SE, Lacey, WA 98503, United States (e-mail: Fett.sprunger@comcast.net).
\end{abstract}

survived. This fact raises the question of whether an adverse effect of the medication could have contributed in any way to her death.

Dr. Melo and colleagues reference a study by me and colleagues when mentioning a higher mortality rate due to PPCM in Haiti. In fact, our studies in Haiti document a decrease in the mortality rates from over $50 \%$ to the reported $15.3 \%$ at the end of a 5 -year observation period. ${ }^{4}$ Those findings are for subjects who received available standard, evidence-based therapy for heart failure.

I have also had the privilege to serve as co-director of the Investigations of Pregnancy Associated Cardiomyopathy (IPAC) studies in North America, led by Dr. Dennis M. McNamara, MD, University of Pittsburgh Medical Center. Our 2015 report $^{5}$ of 100 subjects with PPCM showed recovery rates of $72 \%$ at 12 months postpartum; and a mortality rate of $4 \%$. Only 1 of the 100 subjects received prolactin inhibition treatment, the remainder received standard, evidence-based heart failure therapy. The recovery rates in the IPAC group were very comparable to those reported by Haghikia et $\mathrm{al}^{2}$ for subjects receiving bromocriptine treatment in addition to standard heart failure treatment. Adverse events in the IPAC group occurred almost exclusively in those with diagnostic LVEF under 0.30 , showing clearly the importance of early diagnosis for better preserved heart function.

An additional point that I would like to stress is that the use of prolactin inhibition therapy may lead to loss of breast milk, which can be catastrophic for a newborn, particularly in conditions of poverty where alternative nutrition may be neither affordable nor available. ${ }^{6}$ However, I am certain that in their excellent studies, Dr. Melo and colleagues will address this issue. received

August 31, 2016

accepted

September 12, 2016

published online

September 22, 2016
DOI http://dx.doi.org/ 10.1055/s-0036-1593483. ISSN 0100-7203.
Copyright $(2016$ by Thieme Publicações License terms Ltda, Rio de Janeiro, Brazil 


\section{References}

1 Melo MA, Carvalho JS, Feitosa FE, et al. Peripartum cardiomyopathy treatment with dopamine agonist and subsequent pregnancy with a satisfactory outcome. Rev Bras Ginecol Obstet 2016;38(6): 308-313

2 Haghikia A, Podewski E, Libhaber E, et al. Phenotyping and outcome on contemporary management in a German cohort of patients with peripartum cardiomyopathy. Basic Res Cardiol 2013;108(4):366

3 Sliwa K, Blauwet L, Tibazarwa K, et al. Evaluation of bromocriptine in the treatment of acute severe peripartum cardiomyopathy: a proofof-concept pilot study. Circulation 2010;121(13):1465-1473
4 Fett JD, Christie LG, Carraway RD, Murphy JG. Five-year prospective study of the incidence and prognosis of peripartum cardiomyopathy at a single institution. Mayo Clin Proc 2005;80(12): 1602-1606

5 McNamara DM, Elkayam U, Alharethi R, et al; IPAC Investigators. Clinical Outcomes for Peripartum Cardiomyopathy in North America: Results of the IPAC Study (Investigations of Pregnancy-Associated Cardiomyopathy). J Am CollCardiol 2015;66(8): 905-914

6 Fett JD, Murphy JG. Infant survival in Haiti after maternal death from peripartum cardiomyopathy. Int J GynaecolObstet 2006; 94(2):135-136 